\title{
Anaesthetic management of a patient in prone position-advantage of proseal laryngeal mask airway along with review of literature
}

\author{
Yüzükoyun pozisyonda bir hastanın anestezi idamesi- literatür incelemesiyle \\ birlikte proseal laringeal maskenin avantajı
}

Savita Saini, Teena Bansal*

Department of Anaesthesiology \& Critical Care (Prof. Dr. S. Saini, MD, Dr. T. Bansal, DA, DNB), Pt. B.D. Sharma University of Health Sciences, Rohtak (Haryana) India - 124001

\begin{abstract}
General anaesthesia for surgical procedures requiring prone position consists of induction and tracheal intubation in supine position on a trolley and then the patient is turned prone on the operation table and positioned carefully. Even though this approach is familiar to anaesthesiologists, it is time consuming and requires shift of manpower from other tasks to properly position the patient. Alternative to this technique is to ask the patient to position him/ herself in the prone position on the operating table and then inducing anaesthesia with laryngeal mask airway. The major advantages of laryngeal mask airway in prone position are easy reinsertion, a clear airway provided during the recovery phase from anaesthesia and less sequelae as compared to that commonly accompanying tracheal intubation and accidental tracheal extubation.
\end{abstract}

Keywords: Anaesthetic management, prone position, proseal laryngeal mask airway

\section{Özet}

Yüzüstü pozisyon gerektiren cerrahi işlemlerin yapılmasında genel anestezi için, hasta taşıma sedyesinde sırtüstü pozisyonda indüksiyon ve trakeal entübasyonun uygulandıktan sonraameliyat masasına hastanın yüzüstü çevrilerek uygun pozisyona getirilmesi gereklidir. Her ne kadar anestezistler bu yaklaşıma aşina olsalar da, vakit kaybına neden olması ve başka görevde bulunan çalışanların hastanın uygun pozisyona getirilebilmesi için insan gücü kullanımı gerektirmektedir. $\mathrm{Bu}$ tekniğin alternatifi ise hastadan ameliyat masasına yüzüstü yatmasını isteyip, laringeal maske havayolunu kullanarak anestezinin indüklenmesidir.Yüzüstü pozisyondaki laringeal maske havayolunun en önemli avantajları kolaylıkla yeniden yerleştirilebilmesi, anesteziden ayılma sırasında temiz bir havayolu sağlaması ve trakeal entübasyon ile kazara trakeal ekstübasyona eşlik eden sekellerin az görülmesidir.

Anahtar sözcükler: Anestezik yönetim, yüzüstü pozisyon, proseal laringeal maske havayolu

Geliş tarihi/Received: April 25, 2012; Kabul tarihi/Accepted: August 09, 2012

*Corresponding author:

Teena Bansal, DA, DNB, Department of Anaesthesiology \& Critical Care, 2/8 FM, Medical Campus Pt. BD Sharma PGIMS Rohtak-IN-124001 (Haryana). E-mail: aggarwalteenu@rediffmail.com

\section{Introduction}

The prone position is commonly used to provide surgical access to variety of surgeries including microdiscectomy, varicose vein avulsions, and excision of pilonidal sinus and split skin grafting of burns over back. The conventional approach to management of patients for surgery in the prone position is initially to induce anaesthesia in the supine 
position. After tracheal intubation, the patient is turned on to the prone position and positioned carefully so that ventilation is not impeded, venous return is not compromised and all pressure points are protected. Although this method is familiar to anaesthesiologists, it is time consuming and may necessitate a shift of manpower from other tasks to properly position the patient. Alternative to this technique is to ask the patient to position him/herself in the prone position on the operating table and then inducing anaesthesia. The major disadvantage of this approach is that direct laryngoscopy is usually not possible in the prone position and airway management may be difficult. But this problem may be overcome by the use of laryngeal mask airway. Laryngeal mask airway is less invasive than endotracheal intubation. Also, there is less chance of peripheral nerve damage as patients can take comfortable position themselves before induction of anaesthesia [1]. We hereby report a case of burns over back of the body including buttocks and back of legs posted for split skin grafting in prone position.

\section{Case report}

A 30 year old female with burns over back of the body was scheduled for split skin grafting in prone position. She had history of burns one month back due to fire. Burns were present over back including buttocks and back of legs and therefore she could not lie in supine position. There was no other significant positive history. On systemic examination, cardiovascular system and chest were essentially normal. Neck and temporomandibular joint movements appeared normal. She had adequate mouth opening. Investigations i.e. hemoglobin $(\mathrm{Hb})$, bleeding time, clotting time, urine examination, blood urea, blood sugar, serum electrolytes, chest X Ray and electrocardiography (ECG) were within normal limits. General anaesthesia was planned for the procedure. The anaesthetic procedure was explained to the patient and written informed consent was obtained. She was premedicated with tablet alprazolam $0.25 \mathrm{mg}$ and tablet ranitidine 150 $\mathrm{mg}$ in the night and 2 hour before surgery. Because of burns over back, the patient was reluctant to lie down in supine position due to pain. So we decided to induce the patient in prone position using Proseal laryngeal mask airway (PLMA). In the operating room, patient was made to lie in prone position on the operating table over a mattress which was hollow from the centre to allow free abdominal movements. The head ring was elevated with a pillow to avoid undue neck flexion. The head and neck was rotated to the left to provide access for airway management. The hands were placed above the patient's head. A trolley was positioned alongside so that the patient could be rotated rapidly to the supine position should airway management fail. When the patient was comfortable, monitors were attached including blood pressure (BP), oxygen saturation $\left(\mathrm{SpO}_{2}\right)$ and ECG. Intravenous (i.v.) line was secured with $18 \mathrm{G}$ cannula using ringer lactate. Patient was preoxygenated for 3 minutes. Anaesthesia was induced with injection fentanyl $50 \mu \mathrm{g}$ i.v. and propofol $100 \mathrm{mg}$ i.v. with sevoflurane in oxygen $\left(\mathrm{O}_{2}\right)$. When adequate depth of anaesthesia had been achieved, assistant anaesthesiologist opened the mouth by holding the patient's chin and PLMA number 3 was inserted. As the PLMA passed the incisors, patient's chin was released, allowing the tongue to fall forwards, thereby opening up the posterior oropharyngeal space for the PLMA. Cuff was inflated with $20 \mathrm{ml}$ of air and air entry was checked by auscultation which was confirmed by capnography. Vecuronium 4 $\mathrm{mg}$ and fentanyl $50 \mu \mathrm{g}$ were given intravenously. Intraoperative anaesthesia was maintained with sevoflurane in $67 \%$ nitrous oxide $\left(\mathrm{N}_{2} \mathrm{O}\right)$. $\mathrm{BP}$, pulse, $\mathrm{SpO}_{2}$ and ECG were monitored throughout the procedure. At the end of surgery, anaesthesia was discontinued and PLMA was removed when the patient was able to open her mouth to command. Surgery lasted for 45 minutes and was uneventful. As per surgical advice, there were chances of dislodgement of graft in supine position. So patient was shifted to recovery room in prone position. Recovery after anaesthesia was uneventful.

\section{Discussion}

Procedures requiring prone position are traditionally induced, paralysed and intubated in the supine position and then turned face down. Alternative to this approach is asking 
patients to place themselves prone comfortably before anaesthesia is induced. The major disadvantage of induction in prone position is that direct laryngoscopy is usually not possible for tracheal intubation. However this problem may be overcome by the use of laryngeal mask airway (LMA) which we used in the present case [1]. The classic laryngeal mask airway (CLMA) and PLMA are easily inserted in the prone position, unlike the tracheal tube and offer an easily replaceable and secure airway device in the prone position $[2,3]$.

The use of CLMA remains controversial as insertion and ventilation may fail and the airway may not be protected [4]. We used PLMA instead of CLMA in the present case as sophisticated LMA devices with gastric access such as the reusable PLMA may be more suitable as they are better ventilator devices, achieve a more effective seal, probably protect the airway more reliably and facilitate reinsertion in the event of accidental displacement [5].

In prone position, there is potential for a reduction of pulmonary compliance that can affect oxygenation and ventilation if there is restriction to movements of abdomen [2]. This was overcome by the use of a mattress which was hollow from the centre to allow free abdominal movements in the present case.

When the patient is to be positioned prone, the anaesthesiologist should anticipate and plan for the worst case scenario such as loss of airway for any reason. Maintenance of oxygenation is of utmost importance to protect the patient from hypoxic injury [6]. A trolley should be immediately available to make the patient supine in case of emergency. Measures to increase safety are full preoxygenation, tilting the head and neck to the side to improve access to the mouth, fixation with strongly adhesive tape and avoidance of neck compression as this causes airway obstruction. Also, the gastic tube should be left in situ so that it can function as a guide to reinsertion in the event of displacement [7].

Although direct laryngoscopy can be attempted with the patient prone, but the position of the patient is not optimal for this and it is usually not possible. The major advantages of laryngeal mask airway in prone position are easy reinsertion, a clear airway provided during the recovery phase from anaesthesia and less sequelae as compared to that commonly accompanying tracheal intubation and accidental tracheal extubation.

The various studies about use of LMA devices in prone position suggest that use of LMA devices in the prone position is an effective and possibly safe technique. The largest of these studies, a retrospective audit of 245 healthy adults managed with the LMA Proseal by Brimacombe etal [3] found that insertion, ventilation and gastric tube placement was successful in all patients by experienced users. Correctable partial airway obstruction occurred in three patients, but there were no other complications.

Although the prone position is not the standard position for inducing anaesthesia, it is a position in which central venous cannulation, cardiopulmonary resuscitation and semi awake fiberoptic intubation have been done [8-10]. The success of the technique requires not only skill that comes from practice but also confidence and knowledge that at any time it may be necessary to turn the patient supine for emergency management of any problem. To an experienced anaesthesiologist, who is not familiar with this technique, it can be easily learned and practiced. $\mathrm{Ng}$ et al. [2] postulated that insertion of LMA in the prone position can be learned and practiced within 10 supervised cases.

To conclude, laryngeal mask airway can be easily inserted in the prone position and is less invasive than endotracheal tube and offers a secure airway device in the prone position. Also, insertion and removal of LMA devices cause less physiological consequences than those associated with a tracheal tube and thus offer an attractive alternative to the tracheal tube for airway management in fasted patients undergoing surgery in prone position. 


\section{References}

1. Kumar V, Lalitha K, Lone T. Use of classic laryngeal mask airway inserted in prone position for controlled ventilation: a feasibility study. Indian $\mathrm{J}$ Anaesth 2008; 52: 813-7.

2. $\mathrm{Ng} \mathrm{A}$, Raitt DG, Smith G. Induction of anesthesia and insertion of a laryngeal mask airway in the prone position for minor surgery. Anesth Analg 2002; 94: 1194-8.

3. Brimacombe JR, Wenzel V, Keller C. The proseal laryngeal mask airway in prone patients: a retrospective audit of 245 patients. Anaesth intensive care 2007; 35: 222-5.

4. Brimacombe J. Laryngeal mask anaesthesia. Principles and practice. 2 ed. WB Saunders, 2004.

5. Brimacombe J, Keller C. The ProSeal laryngeal mask airway: A randomized, crossover study with the standard laryngeal mask airway in paralyzed, anesthetized patients. Anesthesiology 2000; 93: 104-9.

6. Hung MH, Fan SZ, Lin CP, Hsu YC, Shih PY, Lee TS. Emergency airway management with fiberoptic intubation in the prone position with a fixed flexed neck. Anesth Analg 2008; 107: 1704-6.

7. Lopez AM, Valero R, Brimacombe J. Insertion and use of the LMA Supreme in the prone position. Anaesthesia 2010; 65: 154-7.

8. Sunder-Plassmann G, Locker GJ, Muhm M, Thalhammer F, Laczika K, Frass von Friedenfeldt M. Central venous catheterization in a patient in the prone position. Crit Care Med 1997; 25: 1439-40.

9. Dequin PF, Hazouard E, Legras A, Lanotte R, Perrotin D. Cardiopulmonary resuscitation in the prone position: Kouwenhoven revisited. Intensive Care Med 1996; $22: 1272$.

10. Neal MR, Groves J, Gell IR. Awake fibreoptic intubation in the semi-prone position following facial trauma. Anaesthesia 1996; 51: 1053-4. 